\title{
Using Reverse Osmosis, Electrodialysis, and Nanofiltration to Increase Affordable Desalinated Groundwater Use in Texas Julie Lee
}

Abstract

Droughts and flooding that have impacted Texas have decreased surface water availability, while draining the limited number of non-saline groundwater sources. Therefore, desalination of saline groundwater would be able to supplement the increasing demand of water for industrial and domestic uses. The process would have to be affordable and capable of meeting $\mathrm{WHO}^{1}$ standards for drinking water. Of the current desalination options available, the methods analyzed are reverse osmosis, electrodialysis, and nanofiltration. Of the three options, it was determined that reverse osmosis was the best solution for the desalination of saline groundwater for both industrial and domestic uses. Reverse osmosis filters saline water to meet WHO standards for sodium and chloride ions. Although both RO and electrodialysis processes were effective enough for eliminating total dissolved solids in the sample saline waters, only RO yielded potable water. If this system is successfully implemented, it could supplement the nonsaline groundwater being used for human consumption, as well as yield RO discharge water for residential or industrial uses. As a result, the severe impacts of the reoccurring droughts in Texas can be reduced, while lessening the drainage of the non-saline groundwater reservoirs in Texas. Keywords: Desalinated Groundwater, Reverse Osmosis, Electrodialysis, Nanofiltration, costcomparison, potable water, brackish water desalination

\footnotetext{
${ }^{1}$ World Health Organization
} 
Maneto: The Temple University Multi-Disciplinary Undergraduate Research Journal | 2.1

\section{Document Scenario}

This document proposes an engineering design to desalinate groundwater in Texas for domestic and industrial uses. I envision this design document to be presented to possible government employees or private companies who are interested in a reverse osmosis system to be built in a Texan saline reservoir, such as the Seymour reservoir, which has recently increased in salinity, making it unsuitable for domestic and municipal use. This proposal would be reviewed by engineers in a city water department. I imagine that this proposal would be of interest to those concerned about the recent droughts and resulting drainage of the Texan aquifers, such as environmental researchers.

\section{Executive Summary}

Over the last half-century, Texas has been plagued by severe drought conditions that have created water shortages for cmunities across the state. The conditions have led to reduced economic output, displacement of residents, and destruction of flora and fauna in Texas. These current conditions are projected to continue for the subsequent years, and water use is beginning to be regulated in the state. However, the regulation may not be enough to keep the economic output of the state from decreasing during droughts. A new source of freshwater would be able to supplement the current need, reduce the strain in current freshwater sources, and reduce the strain upon the residents who may need to heavily restrict their daily use. Although there are no other sources of freshwater to utilize in Texas, there are numerous brackish water reservoirs in every region in Texas. This shows that there is potential in brackish water to be able to supply every region with additional freshwater when necessary. Although brackish water is saline, by using desalination technologies to remove the salt, minerals, and other particles, drinkable water can be produced.

The desalinated groundwater must meet a standard of drinking water, whether it is from the World Health Organization or federal authorities, which dictates the total dissolved solids, or TDS, \% salt, bacteria, viruses, and mineral content. The solution would need to be capable of being powered by Texas' energy grid, reasonable to maintain, and should have some variety in 
assembly. The resulting facility should be able to be built near the brackish water source to lower costs of pipe installation and maintenance. The challenges of the project will lie in determining how to maximize the water available for residential and commercial use.

A system that meets these requirements is the reverse osmosis desalination process. This process allows for the desalination of brackish water to produce high-purity water, which can be re- mineralized to produce drinking water. This system uses a semi-permeable membrane and pressure to filter out the minerals in the feed water. There are numerous membrane types available and additional modules that can be added to recycle the energy at the end of the process, which allows for modularity. By supplementing the high-quality water produced in the residents' drinking water supply, the lower quality water can be utilized in irrigation and industry.

Implementation of a desalination system will reduce the current strain in several of the freshwater sources that are relied upon during conditions of drought. The supplemented water will allow for the reservoirs to refill, which is in the interest of environmental groups. The ranching and farming industries will have a source of water to sustain them, which will prevent large drops in revenue and productivity during drought seasons. If successful, Texas will have large amounts of data and knowledge on the implementation of RO systems for brackish water desalination, which can be marketed to other states such as New Mexico, which faces similar concerns with drought. Any surplus water can be sold to pharmaceutical companies, who need large quantities of high-purity water for production and research. If adoption of this system becomes widespread, other competitive desalination industries, such as nanofiltration, will experience a decrease in market. 


\section{Table of Contents}

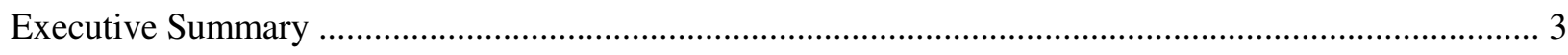

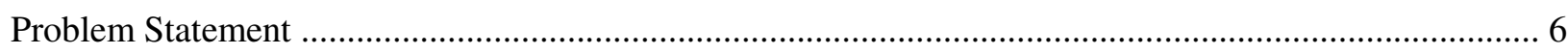

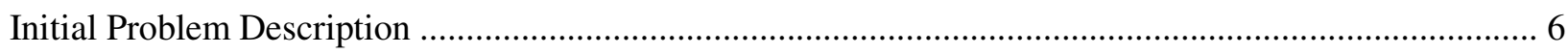

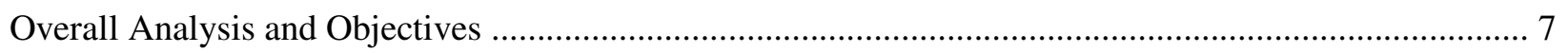

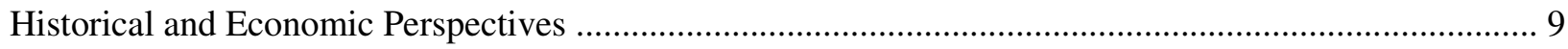

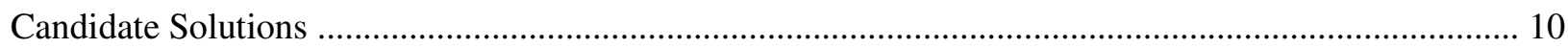

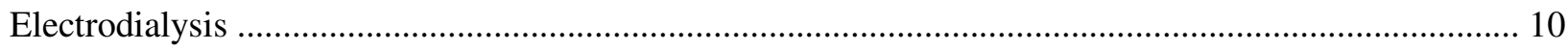

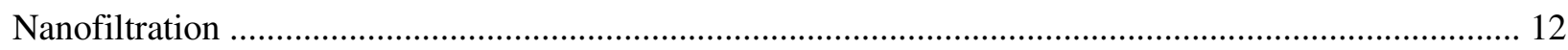

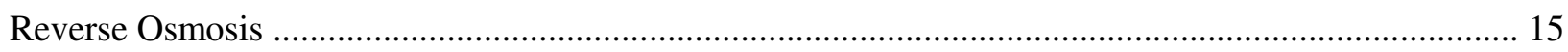

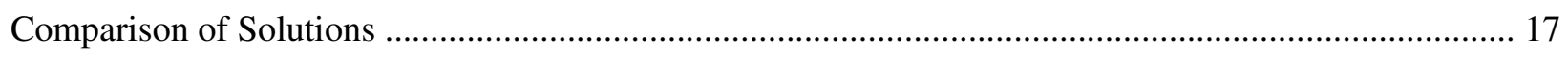

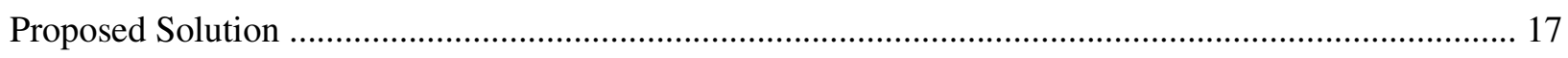

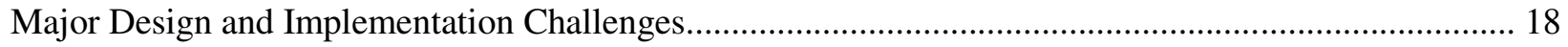

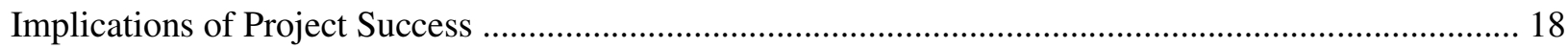

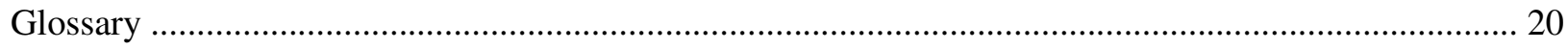

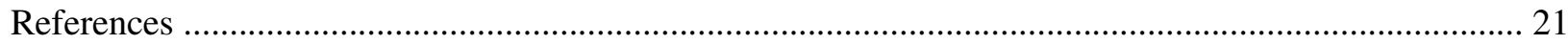




\section{List of Figures}

Figure 1. Schematic drawing illustrating repeating cell pairs .......................................................... 11

Figure 2. Schematic diagram illustrating the principle of electrodialysis ............................................. 12

Figure 3. Schematic diagram of a nanofiltration module .................................................................. 13

Figure 4. A cross-sectional view of a pressure vessel with a spiral-wound RO membrane .................... 16

Figure 5. RO process showing osmosis via applied pressure through a semi-permeable membrane ....... 16

List of Tables

Table 1. Volume of brackish water in the regional water planning areas ........................................... 7

Table 2. Physiochemical analysis of Gabes and Zarzis brackish groundwater and taters and the standards

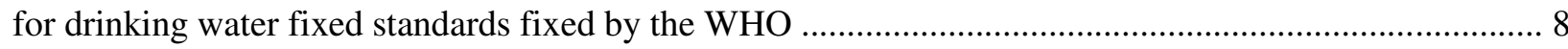

Table 3. Example feed water quality for selected reverse osmosis treatment plants in Texas .................. 8

Table 4. Texas Percent Area in drought conditions from 2000-2017 .................................................... 9

Table 5. Types of thermal and membrane desalination technology ........................................................ 10

Table 6. Commercial nanofiltration membranes with specification of the manufacturers ...................... 14

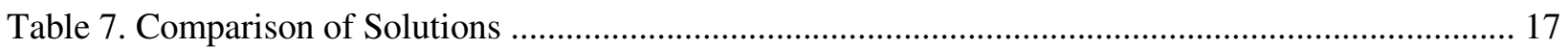


Maneto: The Temple University Multi-Disciplinary Undergraduate Research Journal | 2.1

\section{Problem Statement}

The following sections will demonstrate the need for a desalination system in Texas that can convert brackish water into potable water. The strain on Texas' water sources from the repeated years of drought will be explained, along with some historical perspective as to why a new source of water is crucial to the communities. Using this information, the following sections will investigate the various types of water desalination as candidate solutions, and one will be recommended for further development. Finally, the implementation and potential challenges will be examined.

\section{Initial Problem Description}

Although 70 percent of the Earth's surface is covered by water, less than 1 percent is available for human use. In the last fifty years, global water consumption has increased while the total amount of freshwater available has not seen a significant increase. As a result, water shortage is experienced by arid regions, such as the western U.S., where large areas may have few areas of freshwater sources available.

Brackish groundwater desalination is an increasingly potable option for supplementation of fresh groundwater supply, especially for high use areas such as irrigation. Furthermore, when compared to saltwater desalination, brackish water desalination is more cost-effective and practical alternative in Texas, because fewer solutes generally result in lower operating costs.

Out of U.S. total fresh groundwater withdrawals in 2005, irrigation accounted for 65 percent of use, mostly in western states like California, Texas, Arkansas, and Nebraska (Perlman, U. H., 2010). Out of the total withdrawn groundwater, 96 percent were from freshwater, while the remaining 4 percent was brackish or saline (Perlman, U. H., 2010). This indicates that brackish groundwater desalination may be a possibility for lessening the strain on the fresh groundwater withdrawals.

Although current fresh groundwater withdrawals can provide for the U.S. water usage, if the trend of increased water use coupled with the concerning increase in droughts continues in the coming years, the withdrawals may greatly outweigh the replenishing of the reservoirs. The 
largest uses of freshwater withdrawals are thermoelectric and irrigation, with the third largest use being public supply. Out of irrigation, of the total U.S. water withdrawal data from 2005, 42 percent of water used was groundwater (Perlman, U. H., 2010).

The uses for brackish groundwater include power generation, aquaculture, and oil and gas industry for drilling (National Brackish Groundwater Assessment). If the saline groundwater is able to be treated without incurring high costs, the uses for the treated water would be nearly limitless in the other categories of water use, such as irrigation or municipal use.

The use of saline water for irrigation use is not practical because of the soil degradation and large deposits of unfavorable solutes into the soil. To obtain water acceptable for use in commercial irrigation, removal of solutes is necessary. Treating saline water can quickly become expensive and therefore impractical to put into practice, but recent advances in water treatment technology allow for several methods that allow the process to become feasible. The saline groundwater withdrawal only accounts for a seventh of the total groundwater withdrawal in the U.S. for 2010, but this information indicates the possibility for desalinated groundwater use to become more prominent in the U.S. water use, especially in its industry (Perlman, U. H., 2010). 
Maneto: The Temple University Multi-Disciplinary Undergraduate Research Journal | 2.1

Overall Analysis and Objectives

As it stands, much of the saline groundwater in Texas can only be used for a narrow number of uses, such as irrigation for slightly saline water. All but four of Texas's aquifers are classified as saline. (Kalaswad, S., Christian, B., \& Petrossian, R., 2004). As seen in the Table 1 below there are large quantities of saline water in every region in Texas.

Table 1. Volume of brackish water in the regional water planning areas

\begin{tabular}{|c|c|c|c|}
\hline \multirow[b]{2}{*}{ Region } & \multicolumn{3}{|c|}{ Volume (acre-feet) } \\
\hline & $\begin{array}{l}1,000 \text { to } 3,000 \mathrm{mg} / 1 \\
\text { TDS }\end{array}$ & $\begin{array}{l}3,000 \text { to } 10,000 \mathrm{mg} / 1 \\
\text { TDS }\end{array}$ & $\begin{array}{c}1,000 \text { to } 10,000 \mathrm{mg} 1 \\
\text { TDS }\end{array}$ \\
\hline $\mathrm{A}$ & $7,883,200$ & 11.216 .400 & $19,099,600$ \\
\hline B & $5,952,000$ & $8.583,000$ & $14,535,000$ \\
\hline C & $43,371,200$ & $41,577,700$ & $84,948,900$ \\
\hline D & $28,866,800$ & $26,916,500$ & $55,783,300$ \\
\hline$E$ & $121,871,400$ & $3,511,000$ & $125,382,400$ \\
\hline $\mathrm{F}$ & $267,167,600$ & $105,680,700$ & $372,848,300$ \\
\hline $\mathrm{G}$ & $121,988,600$ & $73,551,800$ & $195,540,400$ \\
\hline $\mathrm{H}$ & $122,571,300$ & $73,298,100$ & $195,869,400$ \\
\hline I & $114,227,300$ & $79,155,200$ & $193,382,500$ \\
\hline $\mathrm{J}$ & $3,201,400$ & $5,436,400$ & $8,637,800$ \\
\hline $\mathrm{K}$ & $101,824,800$ & $100,127,400$ & $201,952,200$ \\
\hline L & $300,957,900$ & $116,809,300$ & $417,767,200$ \\
\hline $\mathrm{M}$ & $270,765,700$ & $125,303,200$ & $396,068,900$ \\
\hline $\mathrm{N}$ & $200,286,200$ & $132,122,600$ & $332,408,800$ \\
\hline 0 & $46,655,400$ & $45,107,400$ & $91,762,800$ \\
\hline $\mathrm{P}$ & $1,364,500$ & $6,461,400$ & $7,825,900$ \\
\hline & $1,758,955,300$ & $954,858,100$ & $2,713,813,400$ \\
\hline
\end{tabular}

NOTES: TDS $=$ total dissolved solids; volumes have been rounded off to the nearest hundred. Source: Modified from data in LBG-Guyton Associates (2003)

(Source: Kalaswad, S., Christian, B., \& Petrossian, R., 2004, p.4)

There is an urgent need for a solution to reduce the current strain on freshwater aquifers and surface water while utilizing the existing potential of the numerous saline aquifers of Texas. Therefore, by implementing a feasible desalinating process for the saline groundwater aquifers, Texas will have an increased supply to supplement the regions which may be suffering from the decreased surface water availability. The increase in freshwater can be applied to irrigation, domestic use, and if treated correctly, can meet industry standards for highly purified water. By matching the current demand for potable water with supplements from desalinated water, the strain on the freshwater aquifers and surface water will be lessened, relieving negative 
Maneto: The Temple University Multi-Disciplinary Undergraduate Research Journal | 2.1

environmental effects such as groundwater depletion. If this project can succeed, it will become a model for future expansion of desalination technologies in other areas in the U.S. The heavy reliance on groundwater replenishment will become lessened as a result.

For a feasible desalination method to be put in place, several requirements should be taken into consideration. The first is cost, which is determined by the size of the facility, the maintenance of the equipment, and the energy required to run the process. To keep the costs of desalinated water in the reasonable range, surveys are recommended to determine which size facility would best suit the characteristics of the saline aquifer. Depending on the equipment and process, the maintenance and energy will vary. This factor should be taken into consideration for budget-conscious groups. The most important, however, would be the water quality, as measured by the WHO standards for potable water, as seen in the third column in Table 2 below. To describe the ideal solution, the resulting facility should be easy to scale based on aquifer size, be relatively easy to maintain, and provide cost efficient desalinated water which meets potable water standards.

Table 2. Physiochemical analysis of Gabes and Zarzis brackish groundwater and taters and the standards for drinking water fixed standards fixed by the $\mathrm{WHO}$

\begin{tabular}{|c|c|c|c|}
\hline & $\begin{array}{l}\text { Gabes } \\
\text { water }\end{array}$ & $\begin{array}{l}\text { Zarzis } \\
\text { water }\end{array}$ & Standards \\
\hline $\mathrm{pH}$ & 7.60 & 7.80 & $6.50-8.50$ \\
\hline Turbiduty (NTU) & 1.6 & 1.8 & 5 \\
\hline Conductivity $\left(\mu \mathrm{S} . \mathrm{cm}^{-1}\right)$ & 4188 & $\$ 400$ & - \\
\hline $\operatorname{TDS}\left(\left.m g\right|^{-1}\right)$ & 2633 & 5292 & 500 \\
\hline Hardness $\left({ }^{\circ} \mathrm{F}\right)$ & 117 & 123 & 50 \\
\hline Alkalinity $\left({ }^{\circ} \mathrm{F}\right)$ & 10 & 14 & - \\
\hline $\mathrm{Ca}^{2+}\left(\mathrm{mg} \mathrm{l}^{-1}\right)$ & 365 & 320 & - \\
\hline $\mathrm{Mg}^{2 *}\left(\mathrm{mg} \cdot \mathrm{l}^{-1}\right)$ & 64 & 106 & - \\
\hline $\mathrm{Na}^{+}\left(\mathrm{mgl} \mathrm{I}^{-1}\right)$ & 409 & 1430 & 250 \\
\hline $\mathrm{K}^{+}\left(\mathrm{mg} \mathrm{I}^{-1}\right)$ & 42 & 55 & - \\
\hline $\mathrm{Fe}^{3+}\left(m g \mathrm{l}^{-1}\right)$ & 0.2 & 0.01 & 0.3 \\
\hline $\mathrm{HCO}_{3}^{-}\left(\mathrm{mg} l^{-1}\right)$ & 120 & 167 & - \\
\hline $\mathrm{SO}_{4}^{2-}\left(\mathrm{mg} \mathrm{l}^{-1}\right)$ & 1040 & 1450 & 400 \\
\hline $\mathrm{Cl}^{-}\left(\mathrm{mgl} \mathrm{l}^{-1}\right)$ & 674 & 1900 & 250 \\
\hline $\mathrm{NO}_{3}^{*}\left(\mathrm{mg} !^{-1}\right)$ & 2 & 12 & 44 \\
\hline $\mathrm{F}^{-}\left(\mathrm{mgl}^{-1}\right)$ & 1.28 & 1.2 & 1.5 \\
\hline
\end{tabular}

Source: (Kalaswad, S., Christian, B., \& Petrossian, R., 2004) 
Maneto: The Temple University Multi-Disciplinary Undergraduate Research Journal | 2.1

Table 3. Example feed water quality for selected reverse osmosis treatment plants in Texas

\begin{tabular}{|c|c|c|c|c|c|c|c|}
\hline Parameters & Fulton & Ballinger & Brownsville & Ft. Stockton & Cameron & Horizon City & El Paso \\
\hline $\mathrm{pH}$ & 7.59 & - & - & - & - & - & - \\
\hline TDS (mg/L) & 2.217 & 1,167 & 3.434 & 2,711 & 4,017 & 1.764 & 2,463 \\
\hline Calcium, $\mathrm{Ca}^{2+}(\mathrm{mg} / \mathrm{L})$ & 31.5 & 100 & 128 & 372 & 201 & 100 & 139 \\
\hline Magnesium, $\mathrm{Mg}^{2},(\mathrm{mg} / \mathrm{L})$ & 27.3 & 50 & 54 & 32 & 71.4 & 23.8 & 37.5 \\
\hline Potassium, $K^{\top}(\mathrm{mg} / \mathrm{L})$ & 16.1 & 10 & 12 & 0 & 16 & 17.6 & 16.7 \\
\hline Sodium, $\mathrm{Na}^{+}(\mathrm{mg} / \mathrm{L})$ & 630 & 180 & 980 & 458 & 1.110 & 445 & 714 \\
\hline Bicarbonate, $\mathrm{HCO}_{2}(\mathrm{mg} / \mathrm{L})$ & 540 & 110 & 357 & 415 & 150 & 88 & 97.6 \\
\hline Chloride, $\mathrm{Cl}^{-}(\mathrm{mg} / \mathrm{L})$ & 615 & 350 & 763 & 696 & 1,150 & 449 & 1,213 \\
\hline Fluoride, F' (mg/L) & 1.4 & 0.4 & 0.9 & 1.5 & 1 & 0.8 & 0 \\
\hline Nitrate, $\mathrm{NO}_{3}(\mathrm{mg} / \mathrm{L})$ & 0.02 & 0.3 & 0 & 6.1 & 2.5 & 0.51 & 0 \\
\hline Sulfate, $\mathrm{SO}_{4}^{-2}(\mathrm{mg} / \mathrm{L})$ & 285 & 350 & 1,100 & 703 & 1,300 & 605 & 248 \\
\hline Silica, SiO ${ }^{2}$ & 22.7 & 12 & 30 & 21.6 & 9.2 & 30.5 & 0 \\
\hline
\end{tabular}

(Source: Batista-Garcia, V., Dahm, K., Guerra, K., \& Tiffenbach, A., 2015, p.22)

Table 3 above shows example feed water quality for several reservoirs in Texas. The table has

columns similar to Table 1, and it can be observed that the water quality of the Gabes and Zarzis represent the extremes of the feedwater in Texas. Therefore, the results from Gabes/Zarzis study will be used to determine the best method for treating the brackish water in Texas.

\section{Historical and Economic Perspectives}

Before October 2010, the most severe drought on record in Texas occurred in the 1950s. The seven-year drought from 1950-1957 is now used as the yardstick upon severe droughts in Texas are measured today. The drought caused damages exceeding the losses of the Dust Bowl and caused the beginnings of water planning in Texas (Burnett, 2012). The drought caused the loss of thousands of cattle, and the decrease of the ranching population in Texas from around a third to less than a quarter, a loss of around 100,000 farms and ranches. To make matters worse, the flood that came afterward caused damages estimated at \$120 million (Burnett, 2012).

Until around 2011, the increased number of reservoirs were enough to serve Texas's water needs. The rainfall only averaged 14.8 inches during 2011, compared to the norm of 60 inches annually. The low rainfall caused the decrease of river and lake water levels, and as of 2014, 70 percent of Texas remained in drought with the state's reservoirs 67 percent full (Everything You Need to Know About the Texan Drought). The drought pattern from the last 17 years can be seen in Table 4 below. 
Table 4. Texas Percent Area in drought conditions from 2000-2017

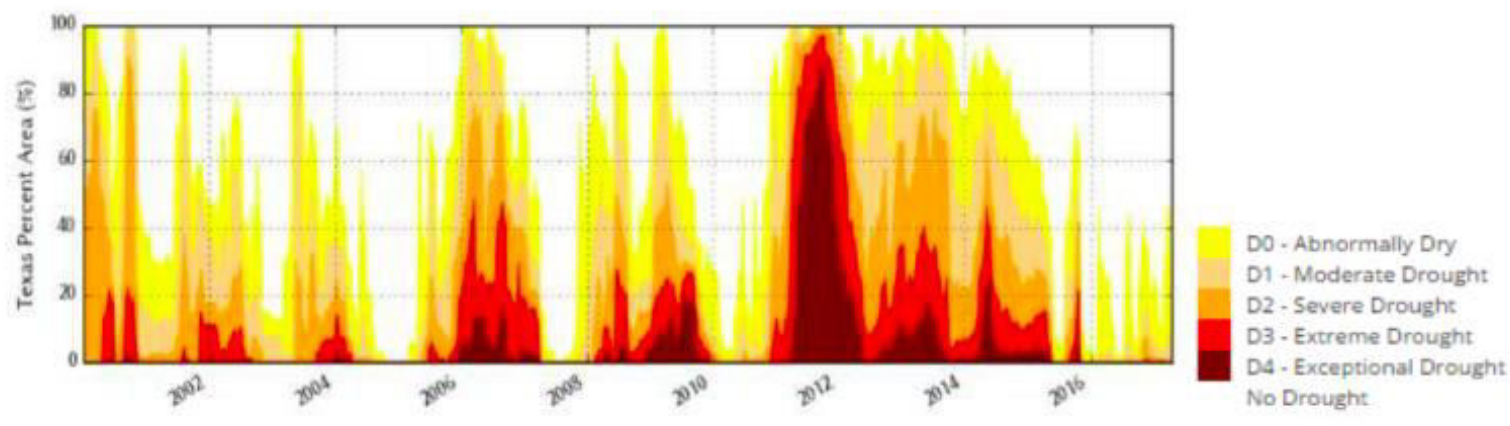

(Source: https://waterdatafortexas.org/drought/drought-monitor)

Following the current trend in the decreased precipitation and long-lasting drought conditions, the deleterious effects of a multi-year drought may soon impact Texas once more. In this case, the water available for the residents to use will be severely limited with the current reservoir levels of freshwater. As of 2011, the drought has caused agricultural losses estimated at $\$ 5.2$ billion and counting (Henry, 2011). Besides the severe economic impact, the environment will also see negative impacts impacting the flora and fauna. According to the NPR, the drought has helped "drain reservoirs, fuel wildfires, ruin crops, and put a real strain on the state's electric grid," (Everything You Need to Know About the Texan Drought). The severity of the situation can best be summarized with these examples: the Bastrop Complex Fire destroyed 34,000 acres and destroyed more than 1300 homes, the town of Spicewood Beach officially ran out of water, and now requires water to be trucked into the town, and corn outputs fell by more than $40 \%$ (Everything You Need to Know About the Texan Drought). The list of damages resulting from the continued drought goes on and on. Trees continue to die from the stressed conditions, roads experience severe deterioration, and food prices continue to fluctuate. To help alleviate these symptoms, Texas has an urgent need to find alternative sources of water to allocate in preparation for the next drought which is sure to take place. 
Maneto: The Temple University Multi-Disciplinary Undergraduate Research Journal | 2.1

\section{Candidate Solutions}

Although there are numerous potential solutions when it comes to desalinating groundwater into a non-saline water, the solutions compared in this document will be focused on methods which yield potable water at a relatively inexpensive cost. The main purpose of this salvaged water would be used during the excessively dry years Texas experiences. This main criterion eliminates solutions which do not produce drinkable water and/or is effective while being affordable.

Table 5. Types of thermal and membrane desalination technology

\begin{tabular}{|c|c|}
\hline Thermal Technology & Membrane Technology \\
\hline Multi-Stage Flash Distillation (MSF) & Electrodialysis (ED) \\
\hline Multi-Effect Distillation (MED) & Electrodialysis reversal (EDR) \\
\hline Vapor Compression Distillation (VCD) & Reverse Osmosis (RO) \\
\hline
\end{tabular}

(Source Krishna, H. J., 2004, p.2)

There are two major divisions of saline water distillation processes: thermal and membrane technologies. The thermal processes are variations of distillation technologies and are best suited for saline water distillation due to high energy costs in operation (Krishna, 2004). One example of thermal technology is the Multi-Stage Flash Distillation or MSF. MSP uses several multi-stage chambers to distil the vaporized water using extreme changes in pressure called "flashing". The tubes require cooling, usually done with incoming feed water. However, MSF processes have serious drawbacks, in that the pipes are prone to corrosion and erosion unless they are built with stainless steel. In addition, the energy required to run this process only allows for countries in the Middle East with inexpensive energy sources to build them. This would drastically limit the locations in which this system can be implemented. These factors eliminate MSF as a potential solution for Texas' water problems.

Another potential solution for desalinating brackish groundwater is the Multi-Effect Distillation or MED. The MED is often used in combination with Vapor Compression 
Maneto: The Temple University Multi-Disciplinary Undergraduate Research Journal | 2.1

Distillation or VCD processes. MED uses a series of vessels to alternate between evaporation and condensation at decreasing pressures (Krishna, 2004). Water boils at lower temperatures as pressure decreases, therefore the water vapor from prior vessels are used to heat the one after; the larger number of vessels yield higher performance. VCD generates the heat needed for evaporating the water from compression of vapors (Krishna, 2004). The drawback is that the VCD units which are used to provide the MED with heat/energy generally have small capacities and are not suitable for large industrial applications. Also, like the MSF process, the energy required to run the system make it more suitable for saline water instead of brackish groundwater desalination.

\section{Electrodialysis}

Electrodialysis, or ED, utilizes stacks of charged, selectively permeable membranes to filter out ions to obtain a channel of filtered water. There are two types of ion-exchange membranes: cation- exchange membranes which are negatively charged, and anion-exchange membranes which are positively charged (Strathmann, H., 2010). The mobile cations in the feedwater are referred to as counter-ions, and the mobile anions are called co-ions. Therefore, the salt ions in a sample of brackish water would become filtered when the cation-exchange membranes attract co-ions, and the anion- exchange membrane attract counter-ions.

The principle of conventional electrodialysis is illustrated in Error! Reference source not found. with a series of anion and cation membranes alternating between two electrodes. The cation-exchange membrane, concentrate containing cell, anion-exchange membrane, and a diluate containing cell is called a cell pair (Strathmann, H., 2010). In industry, the electrodialysis stacks range from 100 to 200 cell pairs, a segment of which is illustrated in Figure 1 (Strathmann, H., 2010). The cation and anion membranes can be used in temperatures above 46 degrees Celsius, are available in different sizes and configurations, and are resistant to changes in $\mathrm{pH}$ from 2 to 9. Overall, the ED system has a long life expectancy (Oztekin \& Sureyya, 2016). 
Maneto: The Temple University Multi-Disciplinary Undergraduate Research Journal | 2.1

\section{Figure 1. Schematic drawing illustrating repeating cell pairs}

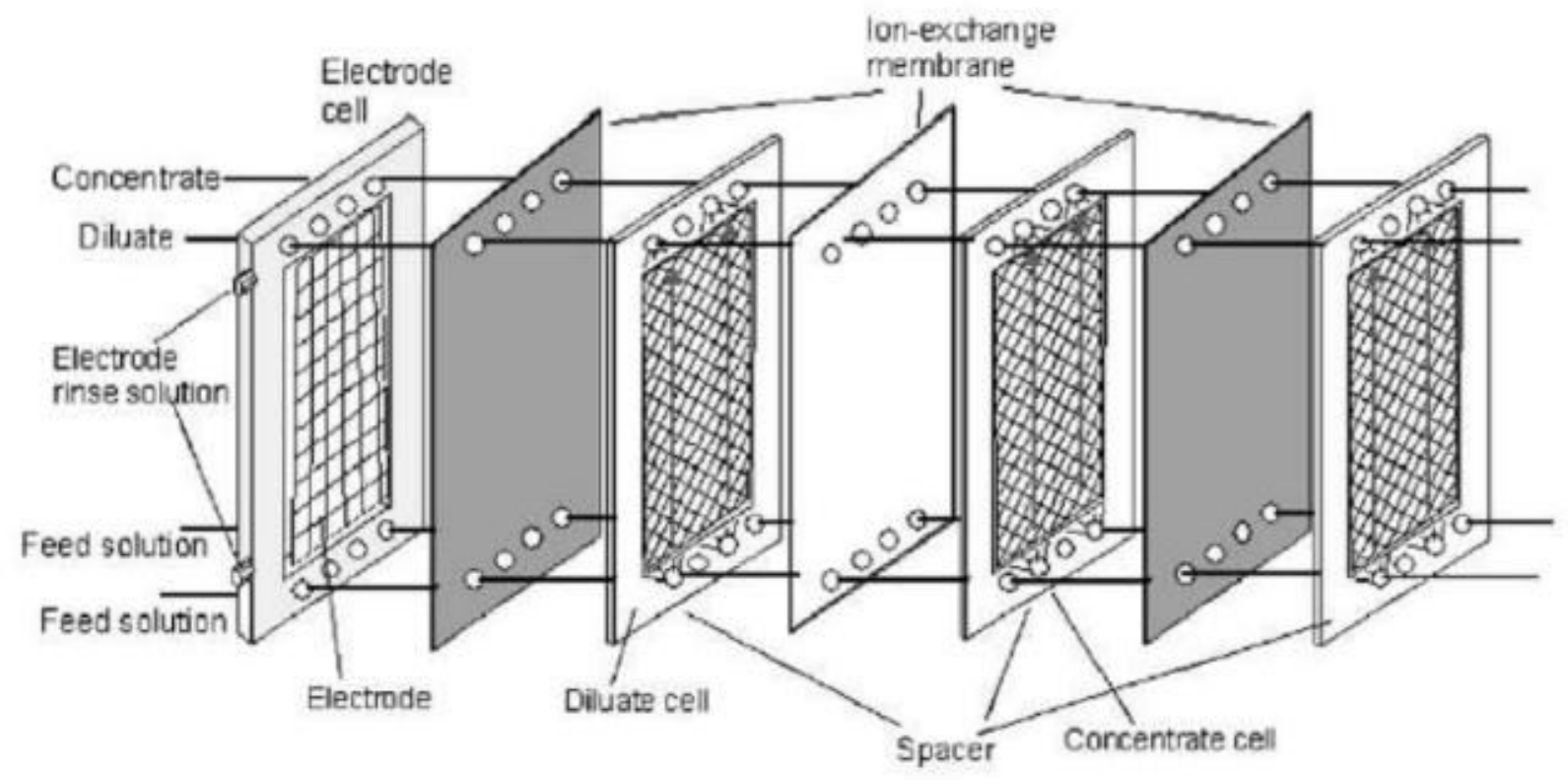

(Source: Strathmann, H., 2010)

Depending on the design of the flow stacks, the flow velocity and pressure varies: for the vertically arranged membrane and spacers, the flow velocity of the feed water is between 2 to 4 $\mathrm{cm} / \mathrm{s}$, with a pressure loss of 0.2 to 0.4 bars, while horizontally arranged the feed flow velocity is 6 to $12 \mathrm{~cm} / \mathrm{s}$ and the pressure loss is between 1 to 2 bars (Strathmann, H., 2010). Therefore, the horizontally arranged stack will provide greater control of polarization and higher limiting current densities, at a cost of a large pressure loss, and vice versa for the vertical. In conventional electrodialysis, the recovery rate is around $50 \%$ of the feed as product water. In cases where the source/feed water has a salinity content of $100 \mathrm{mg} / \mathrm{L}$ to $12000 \mathrm{mg} / \mathrm{L} \mathrm{TDS}$, ED can be used to successfully produce water with TDS content of less than 10mg/L (Oztekin \& Sureyya, 2016). For ED processes, the average $\mathrm{pH}$ range should be from 2-11 and feed water should have temperatures up to 50 degrees Celsius and consumes $0.53 \mathrm{kWh} / \mathrm{m}^{\wedge}-3$. The salt rejection ranges from 50-94 percent (Water Treatment Technology Fact Sheet- Electrodialysis).

Recently, ED systems have been developed to desalinate water that has a greater salt content than seawater. The recent advances and research in this area make this system ideal for use in areas as experimental facilities to test developing technologies as well. Environmentally, this solution has lower energy consumption and takes less space to implement. However, 
pretreatment is still recommended to filter out non-salt particles such as metals. In the study conducted by Walha, Amar, Firdaous, Quemeneur, and Jaouen, the ED treated brackish water in Tunisia successfully treated the water to meet WHO standards (Walha, K., Aar, R. B., Firdaous, L., Quéméneur, F., \& Jaouen, P, 2007, p.105). This result can be compared to the likely result in Texas brackish water since the characteristics of the water are very similar, as seen in Table 2.

An advantage of the electrodialysis system is that in cases where $50 \%$ is not reached, the "feed and bleed operating mode" allows for part of the dilute to be fed back into the feed solution (Strathmann, H., 2010). As a result, very high recovery rates and brine concentrations can be obtained. Other advantages include no osmotic pressure, high-quality product, environmentally friendly due to no usage of chemical treatments, and infrequent maintenance of ion-exchange membranes (Oztekin \& Sureyya, 2016). It is worth mentioning that ED has high permeability selectivity, low electrical resistance, and good mechanical and chemical stability, which are factors that reduce cost. From the study conducted by Walha et al., the Gabes water was successfully desalinated to yield potable water that met the WHO standards.

A major disadvantage of the system is membrane fouling, which reduces the limiting current, flux, ion migration while increasing the membrane resistance (Oztekin \& Sureyya, 2016). These can lead to serious polarization problems and result in a poor quality dilute as a result. Fouling will also increase the cost of operation and maintenance, from having to replace the membranes often to keep the quality of desalinated water high. A minor disadvantage is lack of diversity in the assembly of the components, which would not allow for manipulation in cases where space is limited. 
Maneto: The Temple University Multi-Disciplinary Undergraduate Research Journal | 2.1

\section{Figure 2. Schematic diagram illustrating the principle of electrodialysis}

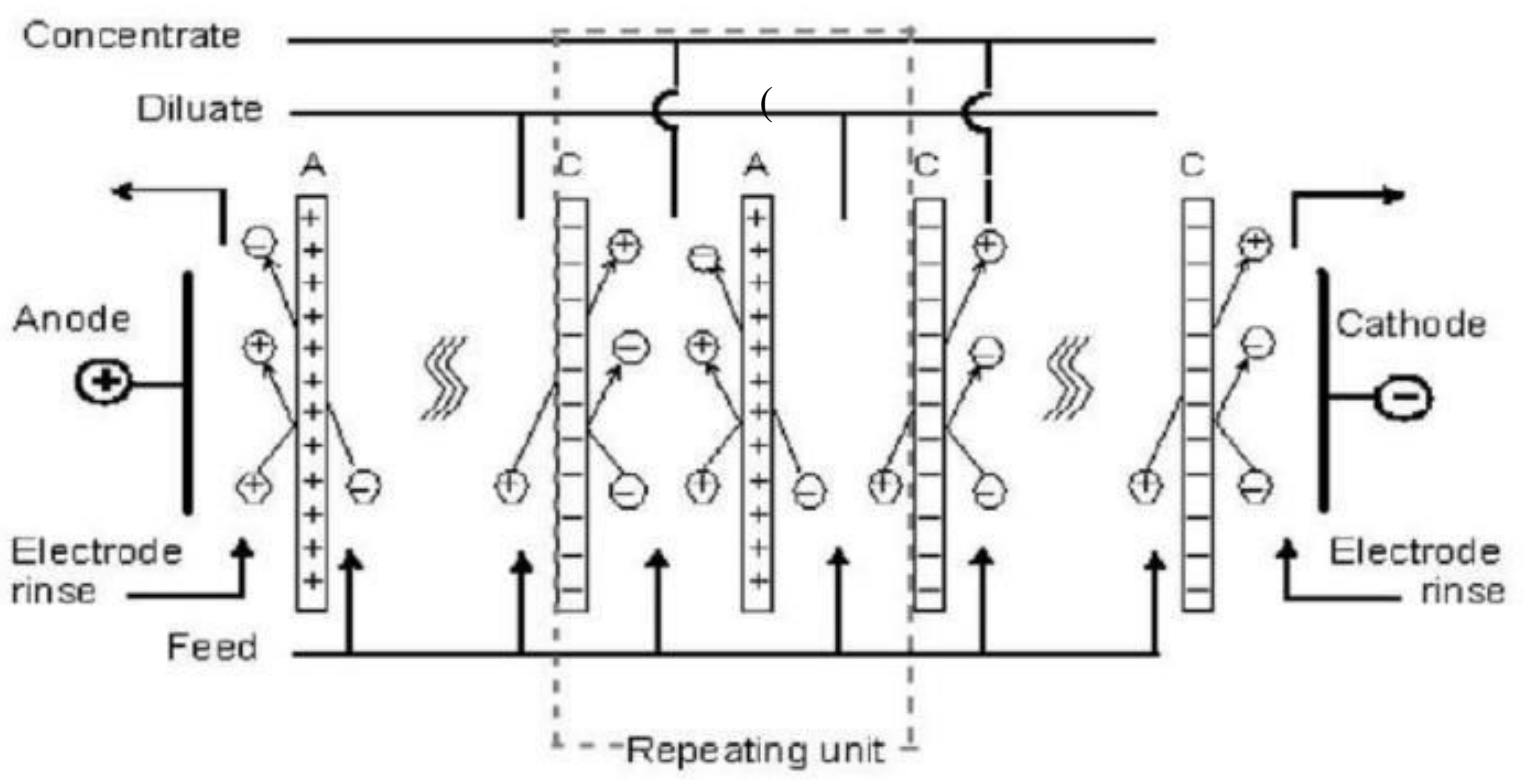

Source: Strathmann, H., 2010

\section{Nanofiltration}

Nanofiltration, or NF, is a membrane driven process that utilizes pressure to selectively restrict the passage of pollutants, specifically ions and low molecular weight organics greater than 1-5nm in size (Shon, H., Phuntsho, S., Chaudhary, D. S., Vigneswaran, S., \& Cho, J., 2013). NF membranes utilize a thin- film composite, polyamide membranes with a thin polyamide skin (Kucera, 2010, p.342). The membranes have pore sizes that are smaller than microfiltration and ultrafiltration, which are other membrane-based methods, but larger than the pores in reverse osmosis, or RO. NF membranes usually operate between 7 to 30 bars and have higher water permeability than RO membranes. NF membranes allow for ions to be separated based on the size and electrical properties, as well as the ion interaction mechanisms. The small size of the membranes' pores allows for even small uncharged solutes to be rejected. NF membranes are most potent in the separation of inorganic salts and small organic molecules (Mohammad, A. W., Teow, Y. H., Ang, W. L., Chung, Y. T., Oatley-Radcliffe, D. L., \& Hilal, N., 2015). As seen below in Figure 3 the simplified diagram of a nanofiltration process shows the use of several manometers to regulate the pressure of the feed water passing through the membrane. Permeates are removed through an attachment, while water is used to cool the apparatus. 
Maneto: The Temple University Multi-Disciplinary Undergraduate Research Journal | 2.1

Figure 3. Schematic diagram of a nanofiltration module

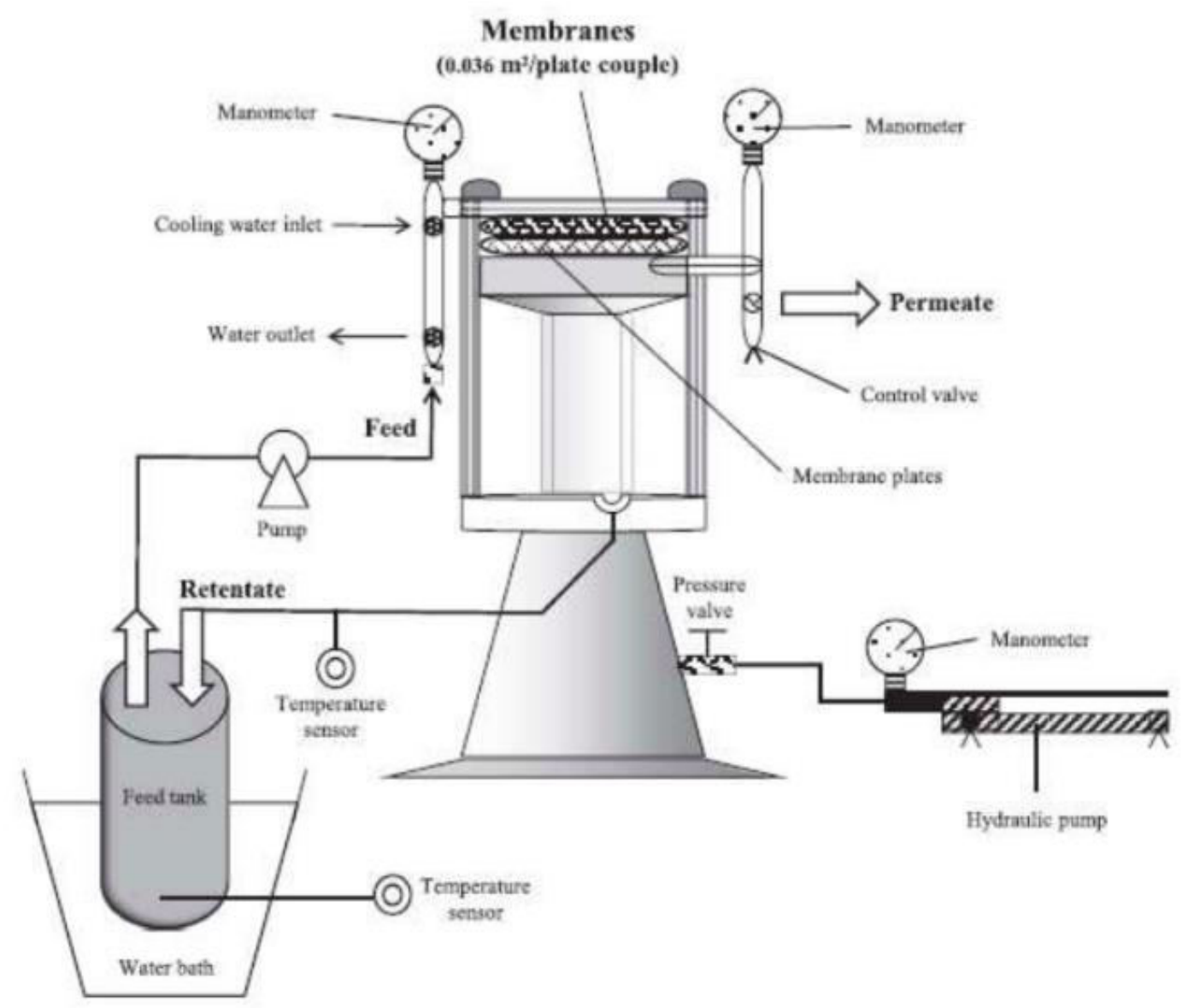

(Source: Galanakis, C. M., Fountoulis, G., \& Gekas, V., 2012) 
Maneto: The Temple University Multi-Disciplinary Undergraduate Research Journal | 2.1

Table 6. Commercial nanofiltration membranes with specification of the manufacturers

\begin{tabular}{|c|c|c|c|c|c|c|}
\hline Membrane & Manufacturer & $\operatorname{MWCO}(\mathrm{Da})$ & Maximum temperature $\left({ }^{\prime} \mathrm{C}\right)$ & $\mathrm{pH}$ range & Stabilized salt rejection ( $\boldsymbol{x}$ ) & Composition on top layer \\
\hline NF270 & Dow filmtec & $200-400$ & 45 & $2-11$ & $>978$ & Polyamide thin-film composite \\
\hline NF200 & Dow Filmtec & $200-400$ & 45 & $3-10$ & $\begin{array}{l}50-65 \times \mathrm{CaCl}_{2} \\
3 \times \mathrm{MzSO}_{4} \\
58 \text { Altrazine }\end{array}$ & Polyamide thin-film composite \\
\hline NF90 & Dow Himter & $200-400$ & 45 & $3-10$ & $\begin{array}{l}85-95 \times \mathrm{NaC} \\
-97 \times \mathrm{CaCb}\end{array}$ & Polyamide thin-film composite \\
\hline 1580 & Trisep & 150 & 45 & 2-11 & 995 & Polyamide \\
\hline TS40 & Trisep" & 200 & 50 & $3-10$ & 998 & Polypiperazineamide \\
\hline XNA5 & Trisep" & 500 & 45 & $2-11$ & 958 & Polyamide \\
\hline UTC20 & Taray & Iso & 35 & 3-10 & 608 & Folypiperazineamide \\
\hline TR60 & Toray" & 400 & 35 & $3-8$ & $55 \pi$ & Goss-linked polyamide composite \\
\hline ak & GE Osmonics ${ }^{A}$ & 2000 & 30 & $5-6.5$ & $94 \pi \mathrm{MgSO}_{4}$ & Cellulose acetate \\
\hline DK & CEE Osmonics & 200 & 50 & $3-9$ & $985 \mathrm{MgSO}_{4}$ & Polyamide \\
\hline DL. & GE Osmonics ${ }^{4}$ & $150-300$ & 90 & $1-11$ & $96 x \mathrm{MgSO}_{4}$ & Cross-linked aromatic polyamide \\
\hline HL. & GE Osmonics ${ }^{d}$ & $150-300$ & 50 & 3-9 & $98 \pi \mathrm{MgSO}_{4}$ & Cross-linked aromatic polyamide \\
\hline NFX & Synder" & $150-300$ & 50 & $3-10.5$ & $\begin{array}{l}99 \mathrm{MjsO}_{4} \\
40 \pi \mathrm{NaCl}\end{array}$ & froprietary polyamide thin-film composite \\
\hline NFW & Synder" & $300-500$ & 50 & 3-10.5 & $\begin{array}{l}975 \mathrm{MESO}_{2} 40 \mathrm{~s} \\
205 \mathrm{NaCl}\end{array}$ & Proprietary polyamide thin-film conposite \\
\hline NFG & Synder" & $600-800$ & so & 4-10 & $\begin{array}{l}505 \mathrm{MgSO}_{4} \\
10 \pi \mathrm{NaCl}\end{array}$ & Proprietary polyamide thin-film conposite \\
\hline TFCSR 100 & Koctf & 200 & 50 & $4-10$ & $>998$ & Proprietary thin-film camposite polyamide \\
\hline SR3D & Koctit & 200 & 50 & $4-10$ & $>998$ & Proprietary thin-fim composite polyamide \\
\hline SHRAPRO & Koctif & 200 & 50 & $3-10$ & 995 & Proprietary thin-film composite polyamide \\
\hline ESNA1 & Nitto-Deniko & $100-300$ & 45 & $2-10$ & $89 x$ & Composite polyamide \\
\hline NTK7450 & Nitto-Denkof & $600-800$ & 40 & $2-14$ & $50 \pi$ & Sulfonated polyethersulfone \\
\hline
\end{tabular}

(Source: Mohammad, A. W., Teow, Y. H., Ang, W. L., Chung, Y. T., Oatley-Radcliffe, D. L., \& Hilal, N., 2015)

Table 6 shows the various specs of the current NF commercial membranes, specifically on the maximum temperature, $\mathrm{pH}$ range, and the salt rejections. According to the figure, it can be observed that although individual membranes have a shortcoming whether it is the narrow $\mathrm{pH}$ range or low maximum temperature, there are other commercial membranes that are competent in the problem area. The average salt rejection of NF membranes are 85-95 percent, can tolerate $\mathrm{pH}$ ranges from 3-10, and pretreatment is recommended (Mohammad et al., 2015). The feed water should have temperatures lower than 45 degrees Celsius, with operating pressure at 70 psi. The recovery rate for NF processes are at $15 \%$ per module, and the membranes do not have variety in assembly.

The NF membranes applications have a wide range. First, the excellent removal capacity for salt ions, lowering prices without sacrificing the lifespan of the membrane, as well as the low energy consumption has made NF ideal for environmental applications such as the treatment of groundwater, surface water, and wastewater reclamation (Mohammad, A. W. et al., 2015). Recent studies show that NF can be used to remove arsenic, persistent organic pollutants, and 
Maneto: The Temple University Multi-Disciplinary Undergraduate Research Journal | 2.1

pharmaceutically active compounds as well, without sacrificing its advantages (Mohammad, A. W. et al., 2015). Also, the survey conducted by the U.S. Department of the Interior determined that "the majority of groundwater wells in Texas could be treated with NF membranes producing a permeate TDS, or total dissolved solids, lower than $500 \mathrm{mg} / \mathrm{L}$," (Batista-Garcia, V., Dahm, K., Guerra, K., \& Tiffenbach, A., 2015, p.35). However, according to a study by Walha et al., the results from desalinating brackish groundwater like Texas's using NF did not result in water that met WHO requirements (Walha et al., 2007, p.105).

Historically, NF systems have been used since the late 80 's, and have been used in a myriad of applications, not limited to: water/wastewater treatment, desalination, pharmaceutical/biotechnology, and food/non-aqueous applications (Mohammad, A. W. et al., 2015). The advantages of NF processes are low operating pressure, high organic rejection, low operating cost, and relatively high water flux (Galanakis, C. M., Fountoulis, G., \& Gekas, V., 2012). In addition, NF offers a relatively low investment and maintenance costs (Galanakis, C. M. et al., 2012). The low operating pressure allows for a lower consumption of energy, which is a valued quality in desalination processes. Also, the lowered operating pressure reduces the rate of fouling in the membranes, thus lowering maintenance costs. Although the pore size of NF membranes is not as small as other commercially available membranes, it exhibits high organic rejection and effectively filters out the salt and other dissolved ions in the feed water while maintaining high water flux. As seen in Table 6, some commercially available membranes are capable of salt rejections greater than $99 \%$. Nanofiltration membranes are also capable of filtering out proteins, viruses, bacteria, and minerals as well, and can produce WHO standard potable water (Kucera, 2011, p.4).

The major disadvantage behind the NF process was membrane fouling, a common problem for all membrane-driven desalination processes. Fouling in membranes limits the membrane operation and cost effectiveness. Fouling also creates an increased energy demand and maintenance, as well as the use of chemicals, all of which can dramatically increase the costs of maintenance and production for any NF system. Fouling has several forms: adsorption, pore blocking, cake layer formation, and gel layer formation ${ }^{2}$ (Mohammad, A. W. et al., 2015). To keep maintenance costs low, the rate at which NF membranes foul should be kept in check. To

\footnotetext{
${ }^{2}$ Refer to Glossary for definitions of the forms of fouling
} 
Maneto: The Temple University Multi-Disciplinary Undergraduate Research Journal | 2.1

prevent and mitigate fouling, feed water analysis is recommended, to test the $\mathrm{pH}$, ionic strength, and turbidity of the feed water so that an appropriate membrane can be selected for NF use. The most effective method of fouling control is to take preventative measures, of which feed water pretreatment is recommended as the best method for reducing fouling (Mohammad, A. W. et al., 2015). Furthermore, in the study conducted by Walha et al., the NF process was unable to produce potable water from the Gabes River water sample.

\section{Reverse Osmosis}

Reverse Osmosis, commonly referred to as RO, is a membrane-based demineralization technique used to separate dissolve solids, such as ions, from solutions (Kucera, 2011, p.3). Like the NF process, the membranes are selective barriers that allows water to flow through them, while retaining the dissolved species, such as ions. Currently, RO membranes offer the highest rejection. Some applications of RO processes include desalination of seawater and brackish water for potable use, microelectronics industry, pharmaceuticals, waste treatment for metal recovery, and food/drink processing industry (Kucera, 2011, p.4).

The simplified theory of how RO processes work is that an applied pressure greater than the osmotic pressure ${ }^{3}$ is applied on the side with the higher number of solutes to push the solvent, in this case, water, through a semi-permeable membrane. This is shown in Figure 5. The actual processes involve using pressure to push feedwater, with $\mathrm{pH}$ ranging from 2 to 12, through a membrane, and creating a stream of permeate water and a stream of concentrated brine. (Krishna, 2004). The average recovery rate of RO feed water 15\% per module (Kucera, 2011, p.56). The RO process has four main steps: pretreatment system, high-pressure pumps, membrane systems, and post-treatment (Krishna, 2004). The pretreatment is used to remove suspended solids so that the rate and severity of fouling can be reduced. In addition, the pretreatment reduces the microbial growth on the membranes. The two preferred methods of pretreatment are chemicals and sand or microfiltration/ultrafiltration (Krishna, 2004). The highpressure pumps supply the pressure to allow the water to pass through the membrane. The pressure ranges from 150 to 800 psi for brackish water desalination (Krishna, 2004). The most widely used membrane type is the spiral wound as seen in Figure 4; the assemblies are constructed from flat sheets of RO membrane wrapped around a central tube which carries the

\footnotetext{
${ }^{3}$ Refer to Glossary
} 
Maneto: The Temple University Multi-Disciplinary Undergraduate Research Journal | 2.1

desalinated water. The post treatment consists of disinfection, stabilization, and adjusting the $\mathrm{pH}$. The energy consumption is $0.81 \mathrm{kWh} / \mathrm{m} 3$.

Figure 4. A cross-sectional view of a pressure vessel with a spiral-wound RO membrane

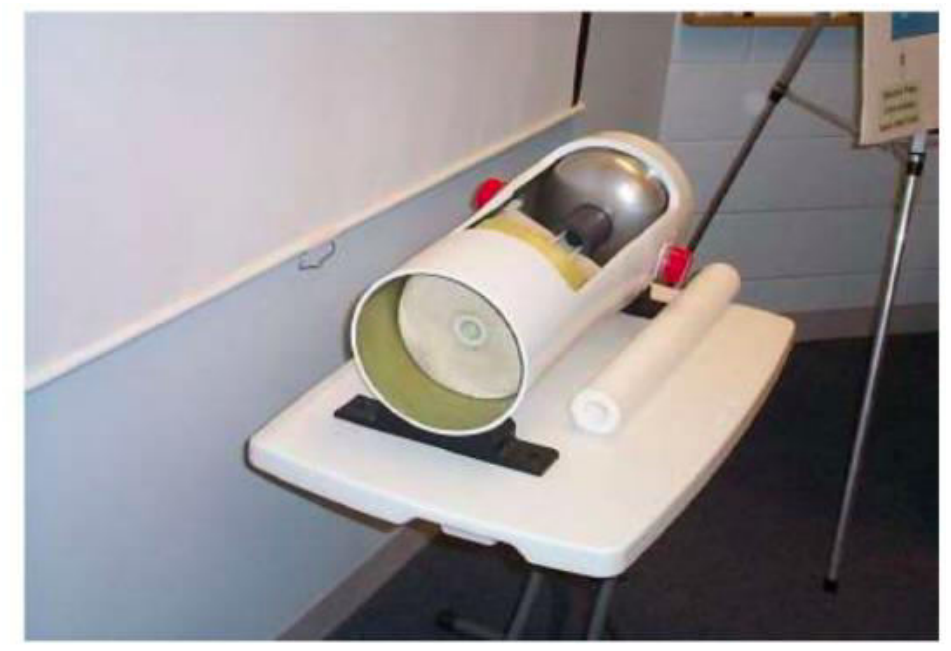

(Source: Krishna, 2004, p.6)

RO processes can produce ultra-pure water that has very low number of ions in the desalinated water; The salt rejection is around 98\% (Kucera, 2011, p.56). However, to turn ultrapure water into potable water, an additional step must be taken to place necessary ions back into the water. This additional step does add costs if potable water is to be produced from the facility.

Figure 5. RO process showing osmosis via applied pressure through a semi-permeable membrane
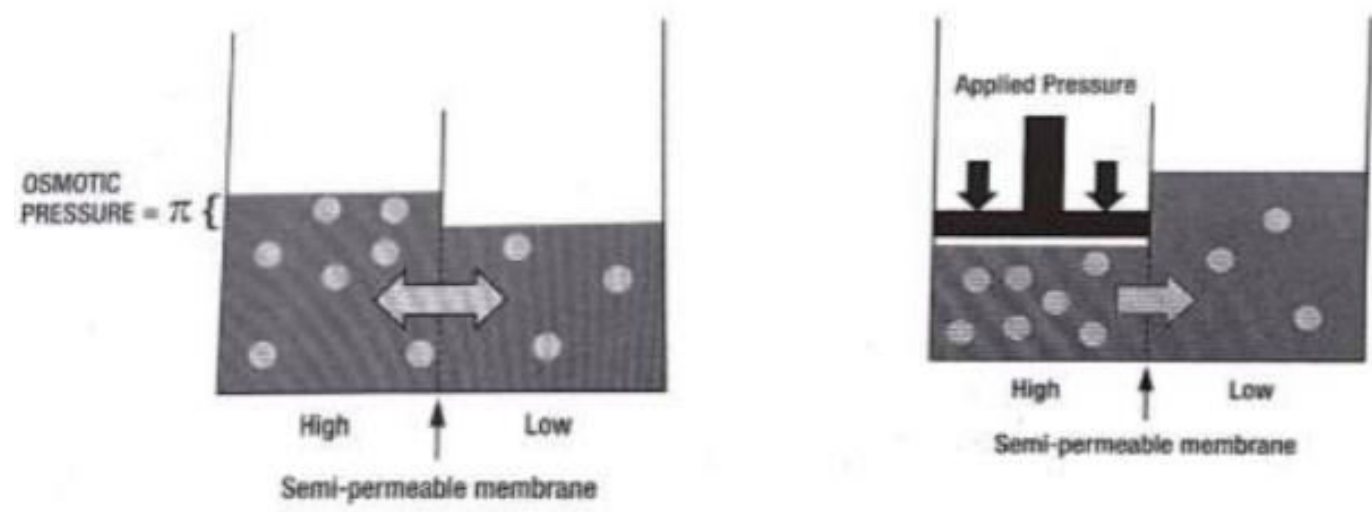

(Source: Kucera, 2011 p.4) 
The advantages of RO processes are the high salt rejection, high-quality permeate, high silica rejection, and large $\mathrm{pH}$ range in the feed water. These characteristics allow for the processing of any type of feed water if pre-treatment is conducted. The high salt and silica rejection, coupled with the rejection of bacteria and viruses, result in potable water that meets the WHO standards. RO is the best method to demineralize or desalinate feed water, as of the time this document is being written. From the study conducted by Walha et al, the RO process was successfully used to desalinate the Zarzis and Gabes water samples to meet WHO standards. Furthermore, the temperature tolerance is greater than 45 degrees Celsius, allowing for a large range of feedwater temperature to be put through desalination without the need for an additional step to temper the water. For industrial use, there are many varieties of RO brackish water membranes, which allows for flexibility in assembly.

The disadvantages of RO processes are the low-pressure, low flux, high energy requirements, required pretreatment, and membrane maintenance. The pressure that RO membranes can be operated at a need to be higher than NF membranes, which increases cost. Although the applied pressure is high, the resulting flux from the membrane remains low compared to NF membranes due to the smaller pore sizes. The RO membranes, like those of NF, are susceptible to fouling, therefore pre-treatment is required to use the membranes for its lifespan. Furthermore, pre-treatment only reduces the rate of fouling, and the membranes must continually be cleaned and replaced as fouling becomes severe. To create potable water through $\mathrm{RO}$ process, the $\mathrm{pH}$ at the end must be adjusted since the removal of ions result in acidic water, and beneficial minerals must be redeposited into the desalinated water. 
Maneto: The Temple University Multi-Disciplinary Undergraduate Research Journal | 2.1

\section{${ }^{4}$ Comparison of Solutions}

\begin{tabular}{|c|c|c|c|}
\hline & Electrodialysis & Nanofiltration ${ }^{4}$ & Reverse Osmosis $^{5}$ \\
\hline Recovery rate $^{6}$ & $50 \%$ & $15 \%$ & $15 \%$ \\
\hline Average $\mathrm{pH}$ range & $2 \sim 11$ & $3 \sim 10$ & $2 \sim 12$ \\
\hline Salt Rejection (\%) & $50-94$ & $85-95$ & $98+$ \\
\hline Feed Pressure (brackish membrane) & $N / A$ & $70 \mathrm{psi}$ & 150-800psi \\
\hline Temperature tolerance (Celsius) & $>50$ & 45 & $<45$ \\
\hline Variety in assembly & Low & Low & High \\
\hline Energy consumption $\left(\mathrm{kWh} / \mathrm{m}^{\wedge}-3\right)^{7}$ & 0.53 & N/A & 0.81 \\
\hline Pretreatment & Recommended & Recommended & Required \\
\hline Meets WHO standard ${ }^{7}$ & Yes & No & Yes \\
\hline
\end{tabular}

\section{Proposed Solution}

Based on the analysis of each of the candidate solutions above as well as the comprehensive comparison chart, the $\mathrm{RO}$ desalination process is recommended for use in treating brackish groundwater in Texas. Although the recovery rate for each module is low, the rate increases dramatically once modules are connected. Of the three solutions, RO has the greatest range in $\mathrm{pH}$ tolerance and highest salt rejection. The temperature tolerance is comparable and competitive with the other solutions. Although the process requires high feed pressure which results in higher energy consumption, the resulting desalinated water goes above WHO standards. Furthermore, the required pretreatment decreases the likelihood of contaminated or otherwise unfit potable water from being produced. Finally, the variety in membranes and methods of arranging the components in RO systems allows for a high variety in assembly, which is a beneficial quality to fit the ranging sizes of Texas' groundwater aquifers. Although ED provides water meeting WHO standards and uses less energy to produce the desalinated water, the quality of the water is still below RO treated water, and therefore has less potential uses. Furthermore, the most popular choice in desalination of brackish water processes

\footnotetext{
${ }^{4}$ Nanofiltration data from DOW FIMTEC NF90-4040

${ }_{6}^{5}$ Reverse Osmosis data from polyamide composite RO membrane (Kucera, 2004)

${ }^{6}$ Per module

${ }^{7}$ From (Walha, K., Amar, R. B., Firdaous, L., Quéméneur, F., \& Jaouen, P., 2007)
} 
Maneto: The Temple University Multi-Disciplinary Undergraduate Research Journal | 2.1

at the time of writing is RO, therefore any problems or concerns can be directed towards experienced plants. With the increased focus and research on nanotechnology, the RO membranes are also expected to become more efficient.

\section{Major Design and Implementation Challenges}

RO systems, with the superior desalination capabilities, incurs high costs in its maintenance and energy use. Therefore, if the state's annual budget does not have enough surplus to introduce this high- cost system, funding can become difficult. In this situation, applying for federal government's assistance and working with environmental groups to raise funds is recommended. Industries such as pharmaceuticals can also be contracted to help with funds in exchange for an exclusive source of high- purity water. When building a RO facility, there should be consultants hired to decide what type of commercial membrane will be the most efficient for each source of brackish water. Depending on the salinity, TDS, and other water quality factors, different membranes will use less energy to produce the same resultant. Another challenge that may come up with installing an RO system is the maintenance of the RO membranes. Although the manufacturer provides manuals for cleaning and replacing membranes, the process has numerous places where common problems occur. In this situation, consulting the manual/manufacturer, and/or a book on frequently asked questions in RO maintenance is recommended. The other concern with RO water is the process of remineralization, where beneficial minerals are reinserted into the treated water for use as potable water. This additional step will add to the already substantial cost in RO processes if the treated water is not only for industrial use but for residential.

Implications of Project Success 
Maneto: The Temple University Multi-Disciplinary Undergraduate Research Journal | 2.1

If the project is successful, communities in Texas will have increased access to freshwater/potable water during the drought conditions that plague the state each year. RO systems will be able to provide water to communities that lack, to prevent displacement of the residents and reduce economic loss. If the $\mathrm{RO}$ water is used for residential needs, then the water that normally comes from the freshwater aquifers can be focused on agricultural and general industrial use.

This process would appeal to government employees and/or private companies who are concerned about Texas's recent decrease in available freshwater. The construction of RO facilities would revive the areas where the drought has negatively impacted the industry, such as the farming communities who were displaced when the freshwater became depleted. This facility would not only provide jobs for the community but also potentially increase the normal yield/production of the area during summer, when drought conditions are at its worst. In addition, by using the saline groundwater, the drainage of the freshwater aquifers can be lowered to allow for the strained reservoir to refill to normal capacity. This aspect would appeal to environmentalists and the state's water department.

The success of this process will also stimulate interest in desalinated water for supplementing water supplies and will lead to the development of more efficient RO membranes and other components that can make RO more efficient. As of writing this document, one example of this is the combination of RO and NF processes which produces the same high-purity water but with less energy consumption. Another technology being explored recently is the addition of power generators that use the precipitate water and pressure to recycle the energy invested into the process. 
Maneto: The Temple University Multi-Disciplinary Undergraduate Research Journal | 2.1

Glossary $^{8}$

Adsorption" — "Specific interaction between the membrane and solutes. It may occur on the membrane

surface or in pores"

Cake layer formation" — "Deposition of particles which grows layer by layer on the membrane surface.

Usually caused by particles with size larger than the pore size of membrane”.

Diluate - Streams of concentrate.

Feed water ${ }^{10}$ - Water which is fed to a system such as a boiler or cooling tower.

Gel layer formation" — "Concentration polarization leads to the formation of gel layer in the immediate

vicinity of the membrane surface"

$\mathrm{Mg} / \mathrm{L}$ - Milligrams per liter

Nanofiltration - "A membrane filtration process used most often with low total dissolved soilds water such as surface water and fresh groundwater, with the purpose of softening (polyvalent cation removal) and removal of disinfection by-product precursors such as organic matter and synthetic organic matter".

Pore blocking — "Solutes block and clog the pores of membrane. The size of particles will decide

whether the pores of membrane will be partially or fully blocked"

Ppm - see $\mathrm{Mg} / \mathrm{L}$

Psi — Pounds per square inch

Reverse Osmosis — "Water purification technology that uses a semipermeable membrane to remove

ions, molecules, and larger particles from drinking water"

Slightly saline groundwater11-1000 to $3000 \mathrm{mg} / \mathrm{L}$ TDS, or milligrams per liter of total dissolved solids.

Saline groundwater11 -3000-10000 TDS

TDS — Total dissolved solids

\footnotetext{
${ }^{8}$ All definitions are from Wikipedia unless specified.

${ }^{9}$ Mohammad, A. W., Teow, Y. H., Ang, W. L., Chung, Y. T., Oatley-Radcliffe, D. L., \& Hilal, N., 2015

${ }^{10}$ http://www.engineering-dictionary.org/ 11 Kalaswad et al., 2004
} 
Maneto: The Temple University Multi-Disciplinary Undergraduate Research Journal | 2.1

\section{References}

Batista-Garcia, V., Dahm, K., Guerra, K., \& Tiffenbach, A. (2015, May). Treating Brackish Groundwater in Texas: A Comparison of Reverse Osmosis and Nanofiltration [PDF]. U.S. Department of the Interior.

Burnett, J. (2012, July 07). How One Drought Changed Texas Agriculture Forever. Retrieved April 26, 2017, from http://www.npr.org/2012/07/07/155995881/how-one-droughtchanged-texas- agriculture-forever

Everything You Need to Know About the Texas Drought. (n.d.). Retrieved April 26, 2017, from https://stateimpact.npr.org/texas/tag/drought/

Galanakis, C. M., Fountoulis, G., \& Gekas, V. (2012). Nanofiltration of brackish groundwater by using a polypiperazine membrane. Desalination, 286, 277-284.

Henry, T. (2011, November 29). A History of Drought and Extreme Weather in Texas. Retrieved April 26, 2017, from https://stateimpact.npr.org/texas/2011/11/29/a-history-of-droughtand-extreme- weather-in-texas/

Kalaswad, S., Christian, B., \& Petrossian, R. (2004). Brackish Groundwater in Texas. The future of desalination in Texas, 2, 9-21.

Krishna, H. J. (2004). Introduction to desalination technologies. Texas Water Development, 2. Kucera, J. (2011). Reverse osmosis industrial applications and processes. Hoboken, NJ: Wiley.

Mohammad, A. W., Teow, Y. H., Ang, W. L., Chung, Y. T., Oatley-Radcliffe, D. L., \& Hilal, N. (2015).

Nanofiltration membranes review: Recent advances and future prospects. Desalination, 356, 226254.

Oztekin, E., \& Altin, S. (2016). Wastewater treatment by electrodialysis system and fouling problems. Turkish Online Journal of Science \& Technology, 6, 91-99.

Perlman, U. H. Total Water Use in the United States, 2010. Retrieved April 26, 2017, from 
Maneto: The Temple University Multi-Disciplinary Undergraduate Research Journal | 2.1

https://water.usgs.gov/edu/wateruse-total.html

Shon, H., Phuntsho, S., Chaudhary, D. S., Vigneswaran, S., \& Cho, J. (2013). Nanofiltration for water and wastewater treatment-a mini review. Drinking Water Engineering and Science.

Strathmann, H. (2010). Electrodialysis, a mature technology with a multitude of new applications. Desalination, 264(3), 268-288.

Walha, K., Amar, R. B., Firdaous, L., Quéméneur, F., \& Jaouen, P. (2007). Brackish groundwater treatment by nanofiltration, reverse osmosis and electrodialysis in Tunisia: performance and cost comparison. Desalination, 207(1-3), 95-106.

Water Treatment Technology Fact Sheet-Electrodialysis [PDF]. (n.d.). ALL Consulting. 